\title{
Trend Information System Research Topics in the SINTA Journal for the Period 2015-2019
}

\author{
Lailatul Muniroh $^{[1]^{*}}$, Dwi Rolliawati ${ }^{[2]}$, Yusuf Amrozi ${ }^{[3]}$ \\ Faculty Of Science And Technology, Information Systems Study Program ${ }^{[1], ~[2], ~[3]}$ \\ State Islamic University of Sunan Ampel Surabaya \\ Surabaya, Indonesia \\ lailaniro@gmail.com ${ }^{[1]}$,dwi_roll@uinsby.ac.id ${ }^{[2]}$,yusuf.amrozi@uinsby.ac.id ${ }^{[3]}$
}

\begin{abstract}
Information systems discipline has developed rapidly over time. Based on 533 information systems study programs in Indonesia, it is possible to have a variety of information systems research topics. However, there is no research on information system topic trends in Indonesia. So this study aims to determine the trend of Information Systems research in Indonesia, which was published in 2015 to 2019 based on the publication of the SINTA journal. The method used is qualitative non-interactive because it analyzes published documents resulting from data collected from the Google Scholar database using Publish or Perish tools. The research flow adopts the recommended PRISMA in improving the quality of the systematic review and better understanding of the readers. Determination of research topics based on abstract content, keywords, and referring to the IS ACM Curriculum and previous research. Research results can be used as academic references to gain new insights into the field of Information Systems. The results of the study obtained 1065 data which were processed based on the publications of the journal SINTA2, SINTA3, and SINTA4 shows that the topic "Application Development" is a trending topic from year to year with a percentage of $31 \%$, the second trending topic is "Decision Support Systems" with a percentage of $11 \%$ and trend of the third topic "System Analysis and Design" with a percentage of $10 \%$. The new issues that arose were "Internet of Things", "Machine Learning" and "Artificial Intelligence". Information systems research in Indonesia varies widely, although some studies have a low percentage.
\end{abstract}

Keywords-Information System, PRISMA, Publish or Perish, Research, Trend Analysis

\section{INTRODUCTION}

Information systems discipline is a pluralistic field that is built based on other knowledge which is considered more established[1]. The information systems discipline focuses on the disciplines of engineering, computer science, management science, mathematics, and decision-making theory. The current information system discipline has become a reference for other fields because it has wide coverage in various fields such as manufacturing, services, agriculture, health, education, security, and government[2]. The diversity of perspectives means that information systems are a field that is valued as either a scientific discipline or a research field. The relevance of the development of information systems research appears more clearly in the information systems conference, namely the European American International Conference. The recent evolutionary examination of information systems research focuses on a broader business perspective topic and includes contributions outside the context of business operations [3].

Research on information system topic trends abroad has been widely conducted, such as Jeyaraj and Zadeh. who analyzed the evolution of information systems research using modeling techniques. Based on information systems research publication data taken from the Web of Science database for the years 2003-2017. The results of this study found that the topics "IS Implementation", "IT Adoption, and" IS Development "were the top topics in all journals and all year. And new issues that have emerged are "blockchain's", "internet of things (IoT)", and "machine learning"[4].

Meanwhile, in Indonesia, Bahruni and Fathurrahmad analyzed trends in research topics on the Web of Science and SINTA for determining student final assignments. The method used was Text Mining by indexing words. The results of these studies indicate that the words "Learning", "Network", "Analysis" and "System" are the top keywords [5]. However, the data used in this study are not entirely journals from Indonesia or mixed with publications from abroad. However, the trend of information systems research topics in Indonesia is still unknown. Research by Nur Rohmaniar was analyzing trends in the use of IT frameworks in Indonesia in 2014-2018. The method used was descriptive quantitative. Based on published data from the Google Scholar database, results showed that the framework often used COBIT with a total of 523 articles [6]. However, the weakness of this research is the method used was unstandardized. This research was conducted to improve previous research from published data, focusing more on research on information systems in Indonesia indexed by SINTA 2, 3, and 4. Meanwhile, the method used is to adopt PRISMA (Preferred Reporting Items for Systematic Review).

The purpose of this study is to determine the trend of information systems research topics in Indonesia for the 20152019 period. The data used are Google Scholar publications. Google Scholar is a search engine for finding publication sources and citation data for free. From a comparison of several search engines such as Google Scholar, Microsoft Academic, Scopus, and Web of Science, Google Scholar remains the most comprehensive publication source today[7]. Various publications can be obtained through Google Scholar, 
including scientific journals from various publishers [8].

Retrieval of data using Publish or Perish tools with the keyword Publisher, where Publisher is an Information System Journal which has been indexed by SINTA 2, 3, and 4. The data obtained was valid. Publish or Perish was a tool Developed by Anne Will Harzing. This tool can retrieve and analyze academic citations from various sources such as Google Scholar, Microsoft Academic, Scopus, Web of Science, and Crossref. Data retrieval, data from Publish or Perish tools can be saved to various output formats for further analysis [9].

The research flow used in this study adopted the PRISMA (Preferred Reporting Items for Systematic Review) Flow Diagram. PRISMA is the result of the development of the QUOROM method [10]. PRISMA has 4 stages, namely Identification, Screening, Eligibility and Included. The PRISMA item is a recommended reporting method in improving the quality of systematic reviews and a better understanding of readers [11]. The flow of this study was adopted from PRISMA, which was modified according to research needs.

\section{RELATED WORK}

Overseas researchers have made many efforts in research to determine the evolution of the development of Information Systems. Like research conducted by Prashant Palvia and others reviewing information systems research trends for the period 2004-2013, This research is an update from previous research. Besides, this study also looks at the methods, models, and paradigms that are often used in Information Systems research. Based on 2487 articles taken from the most popular Information Systems journal using modeling techniques. The results of this study indicate that the topics "E-Commerce", "IS usage/adoption" and "IS research" are trends in Information Systems research for the period 20032017. The method that is often used for surveys, multi-tier influence diagram is most often used in describing the research model, and the positive approach is most often used in words [12].

Noor Al-Qaysi and others researched the theory/model of education and Information Systems used to check the acceptance and adoption of social media using a Systematic Review with a research flow adopting PRISMA. Based on 122 articles published in 2009-2018, the results show that the Uses and Gratifications Theory (U\&G) is a theory that is widely used in social media. Besides, the TAM and UTAUT methods are information system models that are widely used for social media acceptance and adoption[13].

Elham Mazaheri and others investigated the topics and methodologies used in information systems as a whole in the 2007-2018 period. Articles taken from the 8 most popular information systems journals. This research was conducted by analyzing the literature, topics, and methodology in general. The results of the research are the topics of E-Commerce/EBusiness, information systems research, and IS use/adoption being the top topics. While the method that is often used is a survey [14].
Research in Korea, namely Chang-Sik Kim and others, examines the trend of information systems research topics using topic modeling. Based on 1,245 articles published by the APJIS (Asia Pacific Journal of Information Systems), Information Systems Review, and The Journal of Information Systems, 2002-2016. The results of this study indicate that the common trend topics are "systems implementation", "communication innovation", and "customer loyalty". And the most popular topics are "system implementation" and "website" [15].

Álvaro Rocha and others present and discuss the latest innovations, results, experiences, and challenge about information systems. Meanwhile, the latest research is "intelligent information systems", "computing intelligence" methods in Information Systems, and new trends in "Business Process Management"[16].

Jiao Wang and others summarize the results related to Interorganizational Information Systems in the Journal on the Web of Science and the Chinese knowledge network. The analysis uses Knowledge Visualization tools and creates a visual analysis. The results of this study are four trends in the field of information systems research which include trust factors, Inter-Organizational Information Systems in "cloud computing", "configuration analysis methods", and "Social Perspectives" [17].

\section{METHODS}

This research is non-interactive qualitative research. It analyzed the document results of journal publication data retrieval using Publish software or Perish. The results of data collection were processed manually using Microsoft Excel software for grouping data based on keywords. To find out statistics and help present data in graphs and diagrams using Microsoft Excel software. The descriptive analysis explained the results of graphs and diagrams in easy-to-understand sentences and to find out the trends in information systems research in Indonesia in 2015-2019. PRISMA Flowchart is a research flow that was adopted and modified according to the needs of this research. The following is a research flow chart.

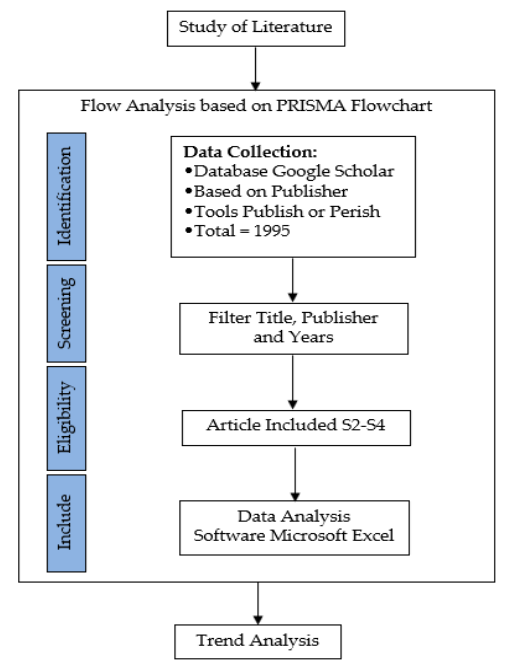

Fig. 1. Research Flow 
The following is an explanation of the chronology research from Fig. 1:

\section{A. Study of Literature}

The literature study stage is the stage of finding references from various relevant readings such as scientific papers, journals, theses, and books related to research.

\section{B. PRISMA Flow}

The PRISMA Flow chart is an analysis used in the systematic review. The PRISMA flow chart used in the study was the result of modification according to the research needs. The following are 4 stages in PRISMA Flowchart, namely:

\section{1) Identification}

Identification is the initial stage of the PRISMA Flow chart. Identification is an early session of the PRISMA Flowchart. Retrieval or collection of research publication data on the Google Scholar database based on Publisher keywords. Data collection using Publish or Perish tools. The publisher is the name of the information system journal indexed in S2-S4. The following Table $\mathrm{I}$ is the name of the indexed journal SINTA 2, SINTA 3, and SINTA 4. Following Table 1 is the Information System Journal data indexed by SINTA 2, SINTA 3 , and SINTA 4.

TABLE I. DATA OF JOURNALS

\begin{tabular}{|c|c|c|}
\hline No & $\begin{array}{l}\text { Category } \\
\text { SINTA }\end{array}$ & Journal Name \\
\hline \multirow{3}{*}{1} & \multirow{3}{*}{ S2 } & Register: Jurnal Ilmiah Teknologi Sistem Informasi \\
\hline & & JSINBIS: Jurnal Sistem Informasi Bisnis \\
\hline & & $\begin{array}{l}\text { Jurnal Sistem Informasi (Journal of Information } \\
\text { System) }\end{array}$ \\
\hline \multirow{5}{*}{2} & \multirow{5}{*}{ S3 } & JURTEKSI: Jurnal Teknologi dan Sistem Informasi \\
\hline & & $\begin{array}{l}\text { INTENSIF: Jurnal Ilmiah Penelitian Teknologi dan } \\
\text { Penerapan Sistem Informasi }\end{array}$ \\
\hline & & Sistemasi: Jurnal Sistem Informasi \\
\hline & & $\begin{array}{l}\text { JATISI (Jurnal Teknik Informatika dan Sistem } \\
\text { Informasi) }\end{array}$ \\
\hline & & TEKNOSI (Jurnal Teknologi dan Sistem Informasi) \\
\hline \multirow{6}{*}{3} & \multirow{6}{*}{ S4 } & Manajerial: Jurnal Manajemen dan Sistem Informasi \\
\hline & & Jurnal Sisfokom (Sistem Informasi dan Komputer) \\
\hline & & $\begin{array}{l}\text { JuTISI (Jurnal Teknik Informatika dan Sistem } \\
\text { Informasi) }\end{array}$ \\
\hline & & JUSIM (Jurnal Sistem Informasi Musirawas) \\
\hline & & JsiI (Jurnal Sistem Informasi) \\
\hline & & Ultima Infosys (Jurnal Ilmu Sistem Informasi) \\
\hline
\end{tabular}

S1 category is not included in the research data because it does not exist in information systems journals.

\section{2) Screening}

Screening is the stage of filtering publication data. Filter publication data by Title, Years, and Publisher. The title filter is carried out on data where the theme or research topic cannot be identified and duplicated so that there is no duplicate data. Publisher filter, namely the deletion of data that is not known to the publisher or the publisher's name does not match the journal in question. Meanwhile, publications other than 2015-
2019 will be removed in Filter Years. The purpose of the Publisher filter is to ensure that the articles are publications of the journal in question and get accurate data. Meanwhile, publications other than 2015-2019 will be removed in Filter Years.

\section{3) Eligibility}

At this stage is the determination of the feasibility of the journal/article, where the publisher of the article/journal must be an information system journal indexed in the SINTA2, SINTA3, and SINTA4 categories. This can be known from the Publisher. The results of the Screening session can be processed directly to the Include stage.

\section{4) Included}

The last stage is the data processing process which is as follows:

- Grouping data based on the category of SINTA

- Grouping data by year

- Determining the research topic by looking at the abstract content and research keywords. As well as using the IS ACM Curricula reference and the results of topic mapping in previous studies.

- Adding and calculating percentages on each resulting topic

- Presents the percentage results in graphical form using the following percentage formula:

$$
\text { Research Topics }=\frac{\text { Number of articles per topic }}{\text { Total articles of all topics }} \times 100 \%
$$

\section{5) Analysis Trend}

This stage is carried out with the help of Microsoft Excel software to perform calculations and present data in the form of tables, charts, and graphs, as well as statistics for each topic. At this stage, a descriptive analysis was also carried out on the processed data to find out the trends of each information system research topic in 2015-2019.

\section{RESULT}

\section{A. Identification}

At the data collection stage, 1731 articles were obtained, where this data will be used in research. The following details the number of articles for each journal as shown in Table II.

TABLE II. DATA OF JOURNAL

\begin{tabular}{|c|c|l|c|}
\hline No & $\begin{array}{c}\text { Category } \\
\text { SINTA }\end{array}$ & \multicolumn{1}{|c|}{ Journal Name } & Total \\
\hline \multirow{2}{*}{1} & \multirow{2}{*}{ S2 } & $\begin{array}{l}\text { Register: Jurnal Ilmiah Teknologi Sistem } \\
\text { Informasi }\end{array}$ & 70 \\
\cline { 3 - 5 } & & $\begin{array}{l}\text { JSINBIS: Jurnal Sistem Informasi Bisnis } \\
\text { Jurnal Sistem Informasi Journal of } \\
\text { Information System) }\end{array}$ & 130 \\
\hline \multirow{2}{*}{2} & \multirow{2}{*}{ S3 } & $\begin{array}{l}\text { JURTEKSI: Jurnal Teknologi dan } \\
\text { Sistem Informasi }\end{array}$ & 72 \\
\cline { 3 - 5 } & INTENSIF: Jurnal Ilmiah Penelitian & 57 \\
\hline
\end{tabular}




\begin{tabular}{|c|c|c|c|}
\hline & & $\begin{array}{llll}\text { Teknologi } & \text { dan } & \text { Penerapan } & \text { Sistem } \\
\text { Informasi } & & & \\
\end{array}$ & \\
\hline & & Sistemasi: Jurnal Sistem Informasi & 194 \\
\hline & & $\begin{array}{l}\text { JATISI (Jurnal Teknik Informatika dan } \\
\text { Sistem Informasi) }\end{array}$ & 115 \\
\hline & & $\begin{array}{l}\text { TEKNOSI (Jurnal Teknologi dan Sistem } \\
\text { Informasi) }\end{array}$ & 125 \\
\hline \multirow{6}{*}{3} & \multirow{6}{*}{ S4 } & $\begin{array}{l}\text { Manajerial: Jurnal Manajemen dan } \\
\text { Sistem Informasi }\end{array}$ & 186 \\
\hline & & $\begin{array}{l}\text { Jurnal Sisfokom (Sistem Informasi dan } \\
\text { Komputer) }\end{array}$ & 410 \\
\hline & & $\begin{array}{l}\text { JuTISI (Jurnal Teknik Informatika dan } \\
\text { Sistem Informasi) }\end{array}$ & 115 \\
\hline & & $\begin{array}{llll}\text { JUSIM } & \text { (Jurnal } & \text { Sistem } & \text { Informasi } \\
\text { Musirawas) } & & \end{array}$ & 38 \\
\hline & & JsiI (Jurnal Sistem Informasi) & 88 \\
\hline & & $\begin{array}{l}\text { Ultima Infosys (Jurnal Ilmu } \\
\text { Informasi) }\end{array}$ & 90 \\
\hline & & Total & 1917 \\
\hline
\end{tabular}

\section{B. Screening}

The first screening is carried out on the Publisher, to ensure that the article is a publication of the journal in question. This is so that the data obtained is accurate. The following Table III is the journal data along with the URL.

TABLE III. NAME JOURNALS AND URL

\begin{tabular}{|l|l|l|}
\hline $\begin{array}{c}\text { SINTA } \\
\text { Category }\end{array}$ & \multicolumn{1}{|c|}{ Journal Name } & \multicolumn{1}{c|}{ URL } \\
\hline \multirow{4}{*}{ S2 } & Register & journal.unipdu.ac.id \\
\cline { 2 - 3 } & JSINBIS & ejournal.undip.ac.id \\
\cline { 2 - 3 } & Jurnal Sistem Informasi & jsi.cs.ui.ac.id \\
\hline \multirow{4}{*}{ S3 } & JURTEKSI & jurnal.stimikroyal.ac.id \\
\cline { 2 - 3 } & INTENSIF & ojs.unpkediri.ac.id \\
\cline { 2 - 3 } & SISTEMASI & sistemasi.ftik.unisi.ac.id \\
\cline { 2 - 3 } & JATISI & jurnal.mdp.ac.id \\
\cline { 2 - 3 } & TEKNOSI & teknosi.fti.unand.ac.id \\
\hline \multirow{5}{*}{ S4 } & Manajerial & ejournal.upi.edu \\
\cline { 2 - 3 } & Jurnal Sisfokom & jurnal.atmaluhur.ac.id \\
\cline { 2 - 3 } & JuTISI & journal.maranatha.edu \\
\cline { 2 - 3 } & JUSIM & jurnal.univbinainsan.ac.id \\
\cline { 2 - 3 } & JSiI & e-jurnal.lppmunsera.org \\
\cline { 2 - 3 } & Ultima Infosys & ejournals.umn.ac.id \\
\hline
\end{tabular}

Title Screening, where the title of the article that cannot be identified as the theme or research topic will be deleted. As well as duplicate data to avoid double data. Meanwhile, publications outside of 2015-2019 and data for which the year of publication is not known will be deleted in Filter Years. The results of the screening are shown in Table IV below.

TABLE IV. RESULT FILTER TITLE, PUBLISHER, AND YEARS

\begin{tabular}{|c|c|c|c|c|c|c|c|}
\hline \multirow[b]{2}{*}{ Journal } & \multirow[b]{2}{*}{ 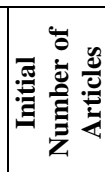 } & \multicolumn{3}{|c|}{ Number of } & \multirow[b]{2}{*}{ 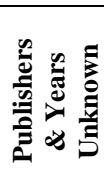 } & \multirow[b]{2}{*}{ 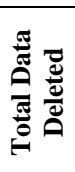 } & \multirow[b]{2}{*}{ 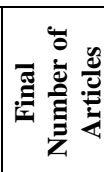 } \\
\hline & & 离 & 密 & 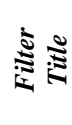 & & & \\
\hline Register & 70 & 17 & 5 & - & - & 22 & 48 \\
\hline JSINBIS & 130 & 30 & 81 & - & - & 111 & 19 \\
\hline Jurnal Sistem & 168 & 3 & 108 & - & - & 111 & 57 \\
\hline
\end{tabular}

\begin{tabular}{|l|c|c|c|c|c|c|c|}
\hline Informasi & & & & & & & \\
\hline JURTEKSI & 72 & - & 5 & - & - & 5 & 67 \\
\hline INTENSIF & 57 & 1 & 10 & 1 & - & 12 & 45 \\
\hline SISTEMASI & 194 & 2 & 21 & 1 & 1 & 25 & 169 \\
\hline JATISI & 115 & - & 25 & - & - & 25 & 90 \\
\hline TEKNOSI & 125 & 3 & 1 & - & 1 & 5 & 120 \\
\hline Manajerial & 186 & 4 & 163 & 13 & - & 180 & 6 \\
\hline Sisfokom & 174 & 1 & 50 & - & 4 & 55 & 119 \\
\hline JuTISI & 410 & 243 & 6 & 6 & 5 & 260 & 150 \\
\hline JUSIM & 38 & - & - & - & - & - & 38 \\
\hline JsiI & 88 & 3 & 11 & - & 1 & 15 & 73 \\
\hline $\begin{array}{l}\text { Ultima } \\
\text { Infosys }\end{array}$ & 90 & - & 26 & - & - & 26 & 64 \\
\hline & \multicolumn{7}{|l|}{ Total } \\
\hline
\end{tabular}

Journal Register with an initial number of 70 articles, a Publisher filter of 17 articles, a Year 5 and 0 filters for the Title filter, the number of deleted articles is 22 , so the final data count is 48 articles. While the JSINBIS Journal (Journal of Business Information Systems) with an initial number of 130 articles, 30 articles deleted in the Publisher filter, filter years 81 , the number of articles deleted was 111 , so the final number was 19 articles. The final data obtained from the screening results are 1065 articles which will be processed at a later stage.

\section{Eligibility}

The stage in determining the eligibility of the article, Publishers is journals indexed by SINTA 2, SINTA 3, and SINTA 4. Because the data in the study are articles published by information systems journals indexed by SINTA 2, SINTA3, and SINTA 4, the data from the Eligibility stage are as shown in Table V.

\section{TABLE V. TOTAL END JOURNAL ELIGIBILITY RESULT}

\begin{tabular}{|c|c|}
\hline Journal & Total \\
\hline Register & 48 \\
\hline JSINBIS & 19 \\
\hline Jurnal Sistem Informasi & 57 \\
\hline JURTEKSI & 67 \\
\hline INTENSIF & 45 \\
\hline SISTEMASI & 170 \\
\hline JATISI & 90 \\
\hline TEKNOSI & 120 \\
\hline Manajerial & 6 \\
\hline Sisfokom & 119 \\
\hline JuTISI & 150 \\
\hline JUSIM & 38 \\
\hline JsiI & 74 \\
\hline Ultima Infosys & 64 \\
\hline Total & 1065 \\
\hline
\end{tabular}

\section{Included}

1065 data will be processed at the Included stage based on the results of the eligibility stage. From 1065 data will be grouped based on the 2015-2019 publication year. In 2015 with a total of 111 articles, in 2016175 articles, in 2017 with a 
total of 264 articles, publications in 2018 with 282 articles, and in 2019 as many as 233 articles. Furthermore, the grouping of data based on categories SINTA 2, SINTA 3 and SINTA4, is done to facilitate data processing. The following Figure 2 is the percentage of publications in each SINTA category which is illustrated in graphic form. The statistics of each SINTA category vary and fluctuate every year. The SINTA 4 category has the highest percentage of publications in 2015-2017, while in 2018-2019 the highest percentage is SINTA 3.

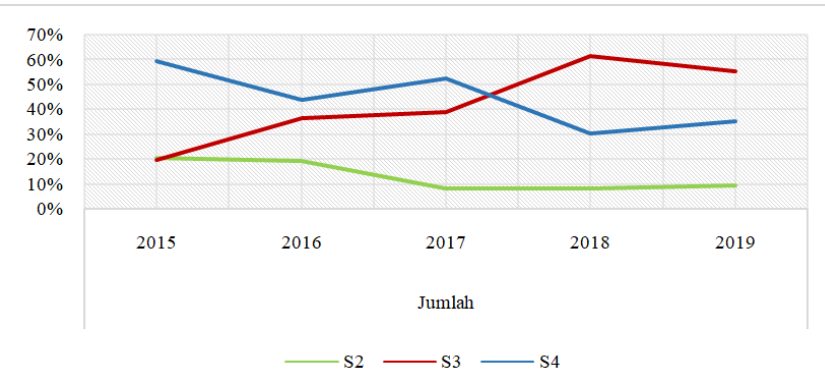

Fig. 2. Results of Publication Statistics Based on SINTA 2015-2019

\section{1) Research Topic Determination Process}

In the process of data processing, identification and determination of article topics are carried out. Manual data processing is by reading the entire title, keywords, and abstract of each article, while in determining the research topic itself refers to the SI ACM Curricula, where this Curricula is a development of the 2002 curriculum and is the result of the collaboration between ACM and AIS [18]. The topic also uses references from previous studies [4], [12], [19]. Determination of research topics is carried out thoroughly and carefully. The results of the research have been reviewed by lecturers with peer knowledge. The following Table VI is a list of the research topics found.

TABLE VI. RESEARCH TOPICS FOUND

\begin{tabular}{|c|l|c|l|}
\hline No & \multicolumn{1}{|c|}{ Topic } & No & \multicolumn{1}{|c|}{ Topic } \\
\hline 1 & Application Development & 20 & $\begin{array}{l}\text { Business Process } \\
\text { Management }\end{array}$ \\
\hline 2 & Decision Support System & 21 & IS Project Management \\
\hline 3 & System Analysis and Design & 22 & Internet \\
\hline 4 & Human-Computer Interaction & 23 & Text Mining \\
\hline 5 & $\begin{array}{l}\text { Data and Information } \\
\text { management }\end{array}$ & 24 & Enterprise System \\
\hline 6 & Expert System & 25 & Business Intelligence \\
\hline 7 & $\begin{array}{l}\text { IT Security and Risk } \\
\text { Management }\end{array}$ & 26 & Digital Image Processing \\
\hline 8 & IT Infrastructure & 27 & Artificial Intelligence \\
\hline 9 & $\begin{array}{l}\text { Geographic Information } \\
\text { System }\end{array}$ & 28 & Social Media \\
\hline 10 & IT Audit and Control & 29 & Games \\
\hline 11 & Forecasting & 30 & E-Learning \\
\hline 12 & $\begin{array}{l}\text { IS Innovation and New } \\
\text { Technology }\end{array}$ & 31 & Otomatization \\
\hline 13 & $\begin{array}{l}\text { Customer Relationship } \\
\text { Management }\end{array}$ & 32 & Internet of Things \\
\hline 14 & Enterprise Architecture & 33 & Machine Learning \\
\hline 15 & $\begin{array}{l}\text { IS Strategy, Management, } \\
\text { and Acquisition }\end{array}$ & 34 & Robot \\
\hline
\end{tabular}

\begin{tabular}{|c|l|c|l|}
\hline 16 & E-Government & 35 & Onology \\
\hline 17 & Enterprise Resource Planning & 36 & E Payment \\
\hline 18 & Intelligence System & 37 & E-Budgeting \\
\hline 19 & Supply Chain Management & 38 & $\begin{array}{l}\text { Search Engine } \\
\text { Optimization }\end{array}$ \\
\hline
\end{tabular}

Based on the data processing of articles in the SINTA 2, SINTA 3, and SINTA 4 categories published in 2015-2019, 38 research topics were found from 1065 articles. Based on the IS ACM Curricula reference, several research themes are grouped under one topic, including "Data and Information Management". The topic of "Enterprise Architecture" consists of the themes of System Integration, Data Integration, IT Service Management, and Enterprise Architecture. The topic "IS Project Management" is a grouping of themes from Schedule Management and Project Management. Analysis and Design, Agile Method, User Interface Design, and UML are grouped under the topic "System Analysis and Design". The themes of IS Planning and IS Strategy are grouped under the topic "IS Strategy, Management, and Acquisition". System Development/Application and Prototyping are grouped under the topic "Application Development". Business Model, Business Process, Statistics, and Business Management are included in the topic of "Business Process Management". "Human-Computer Interaction" grouping of the themes of IS Acceptance, IS Evaluation, Quality Analysis, IS Success, Usability Testing, User Satisfaction, System Analysis, Development Model, Utilization of IS, HCI. "IT Audit and Control" cover the themes of IT/IS Audit, IT Governance, Forensic. The theme of Social Networking, Knowledge Sharing, Knowledge Management, Information Sharing, ECommerce, Web Service, Health Information System is included in the topic "IS Innovation and New Technology". Risk Management, Information Security, Monitoring System, Cryptography, Protected are grouped under the topic "IT Security and Risk Management". Meanwhile, Networking, Cloud Computing, Data Center, Access Performance, IT Infrastructure, and Border Gateway Protocol are grouped under the topic "IT Infrastructure".

\section{E. Trend Analysis}

\section{1) Trends Research Topics by Category of SINTA}

First, trend analysis of SINTA category, Table 6 is a breakdown of data and percentages and the top 15 topics. In the SINTA 2 category, there are 124 articles and the top topic is "Human-Computer Interaction" with a percentage of $13 \%$, "Application Development" 11\%, "Decision Support System" 9\%, and "Digital Images Processing" 8\%. In the SINTA 3 category with 491 articles, it shows that the topics that are often studied are "Application Development" 29\%, "Decision Support System" 14\%, "Data and Information Management" and "Expert System" 7\%. And the SINTA 4 category has 450 articles, where the trend of research topics that are widely studied are "Application Development" with a percentage of 39\%, "System Analysis and Design" 11\%, and "Decision Support System" 9\%. 


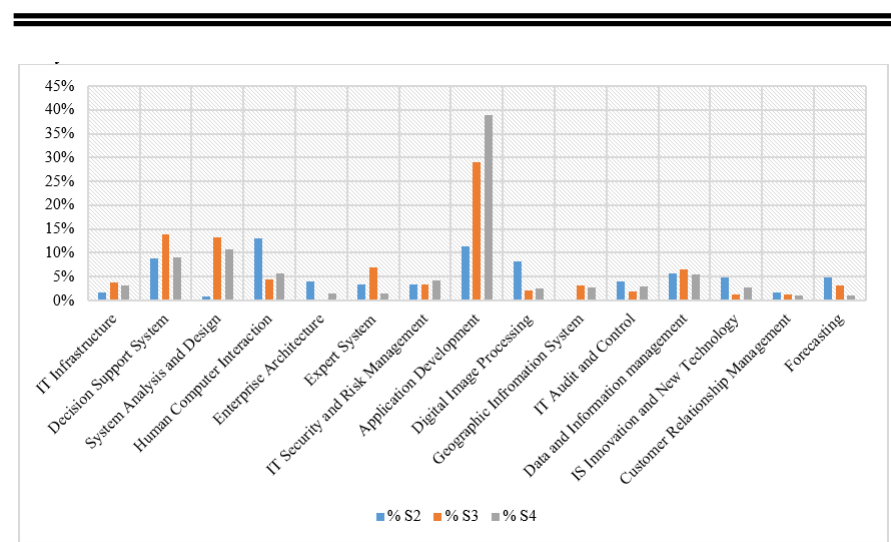

Fig. 3. Information System Topic Trends based on SINTA

\section{2) Trending Research Topics by Years}

The results of the percentage of research topics studied by all journals based on 2015-2019 publications as shown in Figure 4. Figure 4 shows the top 20 trending topics by year. "Application Development" is a trending topic that is often studied, this topic is also a trend from year to year. Figure 4 shows that the top three trending topics in 2015 and 2019 respectively, were "Application Development" Topics, "System Analysis and Design" Topics, and "Data and Information Management" Topics, wherein in 2015 there were 111 articles and 233 articles in 2019. Meanwhile, the top three trends in 2016-2018 are "Application Development" Topics, "Decision Support Systems", and "System Analysis and Design". 2016 with 175 articles, 2017 with 264 articles, and 282 articles from 2018.

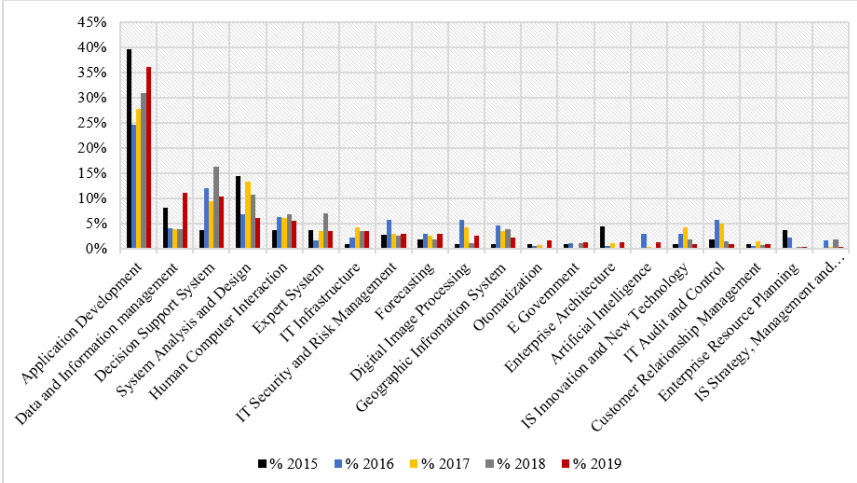

Fig. 4. Trending Research Topics by Year

3) Trends in Research Topics All Journals All Years

There are 38 research topics from all journals and all year. The following Table VII lists the top 20 topics.

TABLE VII. DATA PERCENTAGE OF TOP TOPICS IN ALL JOURNALS ALL YEARS

\begin{tabular}{|l|c|c|}
\hline \multicolumn{1}{|c|}{ Topic } & $\begin{array}{c}\text { Total } \\
\text { Articles }\end{array}$ & $\%$ \\
\hline Application Development & 331 & $31 \%$ \\
\hline Decision Support System & 120 & $11 \%$ \\
\hline System Analysis and Design & 107 & $10 \%$ \\
\hline Data and Information management & 63 & $6 \%$ \\
\hline Human-Computer Interaction & 63 & $6 \%$ \\
\hline Expert System & 44 & $4 \%$ \\
\hline IT Security and Risk Management & 35 & $3 \%$ \\
\hline
\end{tabular}

\begin{tabular}{|l|c|c|}
\hline Geographic Information System & 34 & $3 \%$ \\
\hline IT Infrastructure & 34 & $3 \%$ \\
\hline IT Audit and Control & 31 & $3 \%$ \\
\hline Digital Image Processing & 31 & $3 \%$ \\
\hline Forecasting & 26 & $2 \%$ \\
\hline IS Innovation and New Technology & 24 & $2 \%$ \\
\hline Enterprise Architecture & 12 & $1 \%$ \\
\hline Customer Relationship Management & 10 & $1 \%$ \\
\hline Enterprise Resource Planning & 10 & $1 \%$ \\
\hline $\begin{array}{l}\text { IS Strategy, Management, and } \\
\text { Acquisition }\end{array}$ & 10 & $1 \%$ \\
\hline E-Government & 9 & $1 \%$ \\
\hline Artificial Intelligence & 9 & $1 \%$ \\
\hline Otomatization & 8 & $1 \%$ \\
\hline
\end{tabular}

Table 7 shows that the top percentage for the topic of "Application Development" is 31\%, In the digital era, it is estimated that this topic will continue to increase in the years to come. The top 2 topics were "Decision Support Systems" which reached $11 \%$, while the topics with the top 3 positions were "System Analysis and Design" with a percentage of $10 \%$. 2 topics with a percentage of $6 \%$ namely "Human-Computer Interaction" and "Data and Information Development". While the other 15 topics have a low percentage below 5\%. The percentage results are illustrated in graphical form as shown in Figure 5 below.

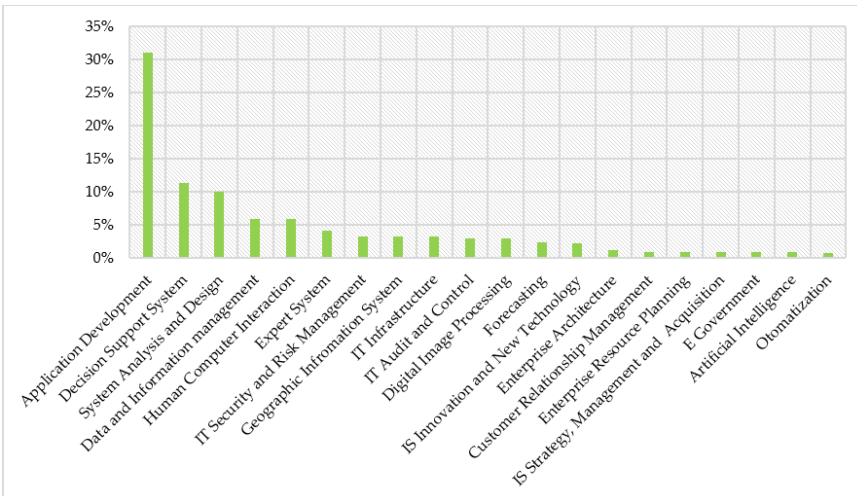

Fig. 5. Trending Research Topics All Journals All Years

\section{DISCUSSION}

The development of research in the field of information systems in Indonesia varies widely, this can be seen based on 1065 published data on SINTA 1, SINTA 2, and SINTA 3 published in 2015-2019. Based on the results of the analysis, it is known that the Topic "Application Development", Topic "Decision Support System", and Topic "System Analysis and Design" are the topics that dominate in every journal and every year of publication throughout 2015-2019. The results of the study are then compared with the results of previous findings or research, as shown in Table VIII below. 
TABLE VIII. COMPARISON OF RESEARCH RESULTS

\begin{tabular}{|c|c|c|c|c|}
\hline \multirow[b]{2}{*}{ Trends } & \multirow[b]{2}{*}{$\begin{array}{l}\text { Results } \\
\text { Research }\end{array}$} & \multicolumn{3}{|c|}{ Results of Previous Research } \\
\hline & & $\begin{array}{l}\text { (Jevaraj \& } \\
\text { Zadeh } \\
\text { 2019) [4] }\end{array}$ & $\begin{array}{c}\text { (Palvia et } \\
\text { al., } \\
2015)[12]\end{array}$ & $\begin{array}{l}\text { (Trihante, } \\
\text { 2017) [20] }\end{array}$ \\
\hline 1 & $\begin{array}{c}\text { Application } \\
\text { Development }\end{array}$ & $\begin{array}{c}\text { IS } \\
\text { Implementation }\end{array}$ & E-Commerce & $\begin{array}{c}\text { Decision } \\
\text { Supp ort } \\
\text { System }\end{array}$ \\
\hline 2 & $\begin{array}{l}\text { Decision } \\
\text { Support } \\
\text { System }\end{array}$ & IS Adoption & $\begin{array}{l}\text { IS Usage/IS } \\
\text { Adoption }\end{array}$ & $\begin{array}{c}\text { Information } \\
\text { System }\end{array}$ \\
\hline 3 & $\begin{array}{c}\text { System } \\
\text { Analysis and } \\
\text { Design }\end{array}$ & $\begin{array}{c}\text { IS } \\
\text { Development }\end{array}$ & $\begin{array}{l}\text { IS Design } \\
\text { and } \\
\text { Development }\end{array}$ & $\begin{array}{l}\text { Expert } \\
\text { System }\end{array}$ \\
\hline
\end{tabular}

Table 8 is the result of the comparison which shows that "Application Development" is a topic that is still consistently studied in Indonesia for the last 5 years. These results are in line with previous research conducted by Anand Jeyaraj [4] and Prashant Palvia [12], it is related to information system artifacts and is expected to continue to be a research center in the field of Information Systems.

The research topic "Decision Support Systems" is still widely studied even though the percentage at the end of the year decreases. In this study the topic "Decision Support Systems" was included in the top two, this result is in line with previous research conducted by Trihanto [20], wherein his research on the topic "Decision Support Systems" became the top trend. The topic of "System Analysis and Design" is how to analyze business processes by involving technology and information systems to support business needs, is that it is very important to analyze and design so that technology or information systems can be used by business needs [18]. In Indonesia, the topic of System Analysis and Design is still widely studied and ranked in the top three in the last five years, although in 2019 it decreased.

The topic "Human-Computer Interaction" is a topic related to the examination of human performance, methods, technology components, and techniques used in designing and evaluating an information system [18]. The topic of "HumanComputer Interaction" covers the keywords of "IS acceptance", "IS success and IS evaluation", "usability testing", "quality system", etc., this topic persisted with the stable presentation during 2015-2019. The topic "Data and Information Management" covers database administration tasks, key data quality, and security concepts. In the data era, this topic is still in demand in Indonesia with a high presentation in 2019, corporate data privacy requires strict security to remain protected.

While other Information Systems research topics have a percentage below 5\%, as shown in Figure 6 below.

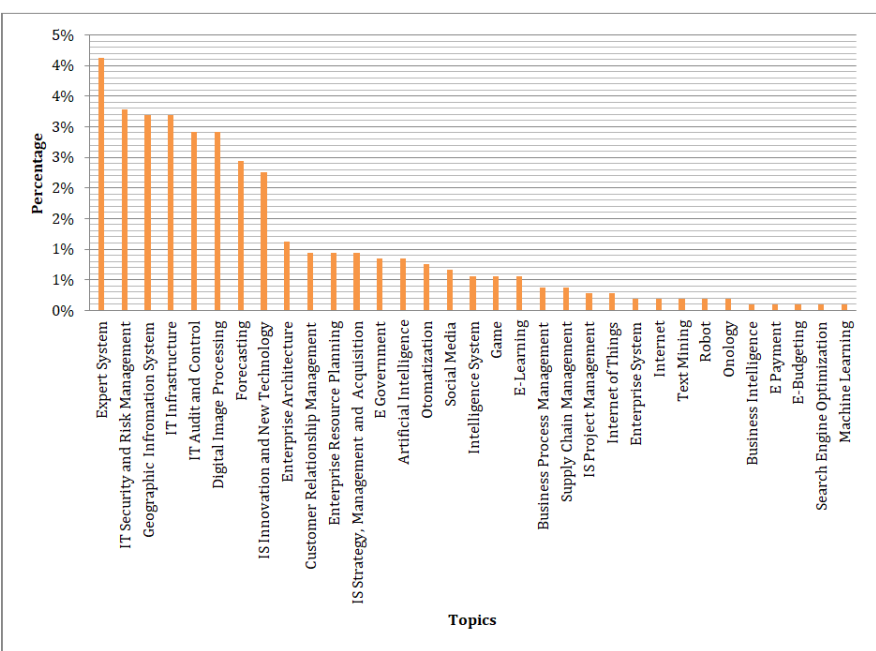

Fig. 6 Topics with a percentage below $5 \%$

New issues that arise following previous research are "Machine Learning", the "Internet of Things", and "Artificial Intelligence" [4].

The limitation of this study is the document analysis method which is done manually one by one, this requires accuracy and a long time to get accurate results. So that further research can use a better method and use the Nvivo Plus tools to analyze qualitative data to make it faster and more accurate. While the limitations in other studies are the data used, namely only the published journals of SINTA 2, SINTA 3, and SINTA 4. Further research can use a lot of data with broad coverage, so the results will be more varied.

\section{CONCLUSIONS}

In this study, we analyzed trends in Information Systems research topics based on publication data in Information Systems journals indexed by SINTA 1, SINTA 2, and SINTA 3 from 2015-2019. This research is a new research theme in the field of Information Systems in Indonesia. Based on 1065 articles that were processed, 38 Information Systems research topics. This shows the development of the discipline of Information Systems in Indonesia. The research topic that is often researched is "Application Development" with the highest percentage, followed by "Decision Support System" and "System Analysis and Design". Meanwhile, some topics have a total of 1 article which means they are rarely researched, such as "Business Intelligence", Search Engine Optimization "and" Machine Learning ". This can inform us of what has been done and what has not been done for future research. By adopting the PRISMA flow the results obtained are more systematic and accurate.

\section{REFERENCES}

[1] J. L. King and K. Lyytinen, Information System The State of the Field. John Wiley \& Sons Ltd, 2006

[2] R. L. Baskerville and M. D. Myers, "INFORMATION SYSTEMS AS A REFERENCE DISCIPLINE,” vol. 26, no. 1, pp. 1-14, 2002.

[3] A. Kupfer, "Research Methods in the Information Systems Discipline: A Literature Analysis of Conference Papers," no. Gable 2010, pp. 1-10, 2018 . 
[4] A. Jeyaraj and A. H. Zadeh, "Evolution of information systems research: Insights from topic modeling," Inf. Manag., vol. 57, no. 4, p. 103207, 2019, doi: 10.1016/j.im.2019.103207.

[5] Bahruni and Fathurrahmad, "ANALISIS TREND TOPIK PENELITIAN PADA WEB OF SCIENCE DAN SINTA UNTUK PENENTUAN TEMA," pp. 13-25, 2018.

[6] N. Rochmania, "ANALISIS TREN PENGGUNAAN FRAMEWORK COBIT, ITIL, DAN ISO 27001 PADA PENELITIAN DI INDONESIA,” 2019.

[7] A. Martín-martín, M. Thelwall, and E. D. López-cózar, Google Scholar, Microsoft Academic, Scopus, Dimensions , Web of Science, and OpenCitations 'COCI : a multidisciplinary comparison of coverage via citations, vol. 0. .

[8] N. Rochmania, I. S. Rozas, and Ilham, "Tren Penggunaan Framework COBIT, ITIL, dan ISO 27001 pada Rentang Tahun 2014-2018 di Indonesia," vol. 4, no. 2, pp. 10-19, 2020, doi: 10.29408/edumatic.v4i2.2249.

[9] D. R. Aulianto, "Pemanfaatan Aplikasi 'Publish Or Perish' Sebagai Alat Analisis Sitasi Pada Pemanfaatan Aplikasi ' Publish Or Perish' Sebagai Alat Analisis Sitasi Pada Jurnal Kajian Komunikasi Universitas Padjadjaran," no. July, 2019.

[10] D. Moher, A. Liberati, J. Tetzlaff, and D. G. Altman, "Academia and Clinic Annals of Internal Medicine Preferred Reporting Items for Systematic Reviews and Meta-Analyses :," vol. 151, no. 4, pp. 264-269, 2009.

[11] H. Vu-ngoc et al., "Quality of flow diagram in systematic review and / or meta-analysis," pp. 1-16, 2018.
[12] P. Palvia, M. D. Kakhki, T. Ghoshal, V. Uppala, and W. Wang, "Methodological and Topic Trends in Information Systems Research: A Meta-Analysis of IS Journals," vol. 37, 2015, doi: 10.17705/1CAIS.03730.

[13] N. Al-qaysi, N. Mohamad-nordin, and M. Al-emran, "of Social Media Acceptance From the Perspective of Educational and Information Systems Theories and Models," 2020, doi: 10.1177/0735633118817879.

[14] E. Mazaheri, "Research Directions in Information Systems Field, Current Status and Future Trends : A literature analysis of AIS Basket of Top Journals," vol. 24, pp. 1-25, 2020.

[15] C. Sik Kim, S. Jung Choi, and K. Young Kwahk, "Investigation of Research Trends in Information Systems Domain Using Topic Modeling and Time Series Regression Analysis,”pp. 1143-1150, 2017.

[16] Á. Rocha, A. M. Correia, H. Adeli, and L. P. Reis, "Recent Advances in Information Systems and Technologies," Adv. Intell. Syst. Comput., vol. 2, 2017, doi: 10.1007/978-3-319-56538-5.

[17] J. Wang, L. Sun, and X. Zhang, "Research Status and Trend of Interorganizational Information Systems Based on Knowledge Visualization," vol. 60, no. Icmesd, pp. 174-184, 2018.

[18] R. T. Wright, K. M. Kaiser, and J. F. Nunamaker, "Curriculum Guidelines for Undergraduate Degree Programs in Information Systems," New York, NY USA, 2010.

[19] N. A. Rakhmawati, Information Systems International Conference (ISICO) 2019. 2019.

[20] W. B. Trihanto, Information Retrieval System Untuk Menentukan Tren Judul Jurnal Bahasa Indonesia Menggunakan Metode TF-IDF Dan Naive Bayes Classifier, vol. 22, no. 1. 2017. 